\title{
KAJIAN STRATEGI PENCAPAIAN MISI TATA KELOLA PEMERINTAHAN KABUPATEN INDRAGIRI HILIR DENGAN KONSEP GOOD GOVERNANCE.
}

\author{
M. Gasali M$^{1}$, Rezky Kinanda², Roberta Zulfhi Surya ${ }^{3}$. \\ ${ }_{1,2}$ Program Studi Teknik Sipil, Universitas Islam Indragiri, Tembilahan \\ ${ }^{3}$ Program Studi Teknik Industri, Universitas Islam Indragiri, Tembilahan \\ Email: sali.mgm@gmail.com (korespondensi)
}

\begin{abstract}
The regional leaders of Indragiri Hilir Regency have their own mission related to governance. The sector which is the basic sector which forms the basis of all local government actions. A sector that is the main vehicle for other regional development sectors. A place where management is enforced in order to produce good governance.

The 2018-2023 Inhil District Government has set one of the missions, namely "Strengthening governance that is more responsive, participatory, innovative, effective and law-abiding". This mission certainly requires a good planning strategy in order to produce good mission achievements.

This journal will present recommendations for good governance strategies to be implemented in Indragiri Hilir Regency according to the potential and resources possessed by Indragiri Hilir Regency.
\end{abstract}

Keywords: Governance, Good Governance, responsive, obeying the law, Indragiri Hilir.

\begin{abstract}
Abstrak
Pemimpin daerah Kabupaten Indragiri Hilir memiliki misi tersendiri terkait tata kelola pemerintahan. Sektor yang merupakan sektor dasar yang menjadi landasan seluruh tindakan pemerintahan daerah. Sektor yang menjadi kendaraan utama bagi sektor-sektor pembangunan daerah lainnya. Tempat dimana manajemen ditegakkan guna menghasilkan tata kelola pemerintahan yang baik.

Pemerintah Kabupaten Inhil 2018-2023 menetapkan salah satu misi yaitu "Memantapkan tata kelola pemerintahan yang makin responsif, partisipatif, inovatif, efektif dan berketaatan hukum". Misi ini tentu membutuhkan strategi perencanaan yang baik guna menghasilkan capaian misi yang baik pula.

Jurnal ini akan menyajikan rekomendasi strategi good governance untuk diterapkan di Kabupaten Indragiri Hilir menyesuaikan dengan potensi dan sumberdaya yang dimiliki oleh Kabupaten Indragiri Hilir
\end{abstract}

Kata kunci: Tata Kelola, Good Governance, responsif, berketaatan hukum, Indragiri Hilir.

\section{LATAR BELAKANG}

Konsep Good Governance telah banyak berkembang di kalangan para ahli. Masingmasing menyampaikan konsep governance yang berbeda-beda. Ada yang berorientasi kepada keberlanjutan, smart, teknologi komunikasi, dll.

Good Governance atau Tata Kelola Pemerintahan yang baik adalah impian setiap daerah. Namun konsep good governance sering kali gagal dilaksanakan dengan baik dikarenakan banyak sebab. Salah satunya adalah kegagalan memahami konsep good governance yang sesuai dengan karakteristik daerah dan orientasi good governance yang kurang kokoh tertanam di benak para pemangku kebijakan.

Dalam penggarapannya good governance sebagai sebuah proses manajemen dimulai dengan Perencanaan, pengorganisasian (jadwal dan anggaran), pelaksanaan, dan evaluasi. Salah satu kegagalan yang membuat good governance ini sering terjadi di daerah-daerah adalah gagal merencanakan strategi good governance. Hal ini masuk ke dalam istilah "gagal membuat rencana sama dengan merencanakan kegagalan". 
Perencanaan akan menjadi landasan untuk evaluasi. Jika rencana yang dibuat tidak kokoh, tidak matang, tidak kuat, maka evaluasi dari pelaksanaan yang telah dilakukan tidak akan memberikan dampak yang besar.

Perencanaan harus memiliki keselarasan antara visi dan misi dengan program dan kegiatan yang dilaksanakan serta memiliki keterkaitan dengan RPJP, RPJM, RKPD, dan peraturan rencana daerah lainnya.

Pemimpin daerah Kabupaten Inhil 20182023 menetapkan salah satu misi yaitu "Memantapkan tata kelola pemerintahan yang makin responsif, partisipatif, inovatif, efektif dan berketaatan hukum"

Tujuannya adalah untuk meningkatkan tata kelola pemerintahan yang bersih dan baik, dengan sasaran tata kelola dan penyelenggaraan pemerintahan serta peningkatan kualitas pelayanan publik.

Jurnal ini akan menjelaskan rekomendasi konsep atau strategi good governance yang disesuaikan dengan karakteristik Kabupaten Inhil, potensi, komposisi pemerintahan, dll.

\section{TINJAUAN PUSTAKA}

\subsection{Konsep Good Governance}

Good governance mengandung dua pengertian (Widodo, 2000), Pertama, nilainilai yang menekankan pada menerima aspirasi rakyat dan nilai-nilai yang dapat meningkatkan kemandirian masyarakat. Serta makna terkait pembangunan berkelanjutan dan keadilan sosial, dengan orientasi pada demokratisasi dalam kehidupan bernegara, dan mengedepankan legitimacy, accountability, authonomy dan devolution of power.

Kedua, aspek-aspek fungsional dari pemerintahan yang efektif dan efisien dalam melaksanakan tujuan dengan orientasi pada bagaimana pemerintahan mempunyai kompetensi serta struktur dan mekanisme politik dan administrasi berfungsi secara efisien dan efektif.

Berkaitan dengan orientasi good governance, Masdiasmo (2002) mengungkapkan bahwa orientasi pembangunan sektor publik adalah untuk menciptakan good governance, dimana pemerintahan yang baik berupaya menciptakan penyelenggaraan manajemen pembangunan yang solid dan bertanggung jawab sesuai dengan prinsip demokrasi, efisiensi, pencegahan korupsi, baik secara politik maupun administratif. Good governance menekankan reformasi peran pada aparatur nasional dan daerah untuk mampu mendukung kelancaran dan keterpaduan pelaksanaan tugas dan fungsi penyelenggaraan pemerintahan dan pembangunan.

Good governance terus berkembang mengikuti perkembangan zaman serta kebutuhannya. Di era masa kini yang sangat terikat dengan teknologi komunikasi, good governance perlahan mengalir kea rah $\mathrm{E}$ Governance. Pada dasarnya konsep ini masih memegang konsep good governance sebagai landasannya hanya saja tools yang digunakan lebih berat kepada teknologi informasi dan komunikasi.

Menurut The Worid Bank Group (Falih Suaedi, Bintoro Wardianto 2010:54), Good Governance bisa berorientasi kepada konsep E-Government sebagai upaya pemamfaatan informasi dan teknologi komunikasi untuk meningkatkan efesiensi dan efektivitas, transfaransi dan akuntabilitas pemerintah dalam memberikan pelayanan publik secara lebih baik.

Konsep Good Governance yang berorientasi kepada teknologi komunikasi ini juga didukung oleh Clay G. Wescott bahwa menggunakan teknologi informasi dan komunikasi untuk mempromosikan pemerintah yang lebih effisien dan penekanan biaya yang efektif, kemudian fasilitas layanan terhadap masyarakat umum dan membuat pemerintah lebih bertanggung jawab kepada masyarakat.

Dalam kategori operasional, beberapa hal yang mendapat perhatian dalam pengembangan E-Government antara lain:

a. Organisasi dan tata kerja pemerintah propinsi perlu mewadahi layanan EGovernment secara efisien dan efektif.

b. Sumber daya manusia perlu dikembangkan keahlian dan ketrampilannya dalam mengelola teknologi informasi dan komunikasi serta diperhatikan penghargaan dan jalur kariernya.

c. Anggaran untuk pemeliharaan perangkat sama pentingnya anggaran untuk pengembangan, maka diperlukan anggaran yang cukup untuk secara terus-menerus memelihara mutu layanan E-Government, antara lain untuk membuat versi baru perangkat lunak, memperbaharui data untuk menyesuaikan kondisi yang berubah, dan menyesuaikan sebagian teknologi yang dipakai untuk teknologi yang lebih baru.

\subsection{Misi Tata Kelola Pemerintahan yang Makin Responsif, Partisipatif, Inovatif, Efektif Dan Berketaatan Hukum}


Pemimpin daerah Kabupaten Inhil 20182023 menetapkan salah satu misi yaitu "Memantapkan tata kelola pemerintahan yang makin responsif, partisipatif, inovatif, efektif dan berketaatan hukum".

Dalam usaha untuk mewujudkan misi di atas. Strategi harus menyasar kepada setiap kata kunci pada misi di atas, yaitu tata kelola, responsif, partisipatif, inovatif, efektif, dan berketaatan hukum. Sasaran-sasaran yang menjadi orientasi good governance Pemerintah Kabupaten Inhil adalah bagaimana mewujudkan tatakelola yang responsif, partisipatif, inovatif, efektif dan berketaatan hukum. Responsif merujuk bagaimana masalah yang terjadi di Kabupaten Inhil bisa ditanganin dengan cepat.

Partisipatif merujuk ke bagaimana seluruh elemen dapat berpartisipasi terhadap pembangunan Kabupaten Inhil termasuk masyarakat.

Inovatif adalah bagaimana kebijakan atau program yang diambil oleh pemerintah harus inovatif.

Efektif adalah bagaimana pemerintah harus memberikan solusi baik kebijakan atau program kegiatan yang efektif.

Terakhir berketaatan hukum merujuk pada setiap elemen baik pemerintah maupun masyarakat harus berjalan di atas aturan hukum yang berlaku.

\section{METOde PENELITIAN}

Metode yang digunakan dalam penelitian ini ada metode kajian pustaka atau kajian teoritis yang kemudian disesuaikan dengan kajian dokumen. Dalam hal ini teori-teori ideal tentang good governance akan disinambungkan dengan misi resmi Pemerintah Kabupaten Indragiri Hilir.

\section{HASIL DAN PEMBAHASAN}

Konsep good governance terus berkembang mengikuti trend dan juga orientasi pembangunan yang dituju. Ada god governance yang berorientasi pada sustainable city, green city, global city, smart city, dan sebagainya. Namun pola yang jalankan tidak akan jauh berbeda. Dasardasar yang menjadi landasan tidak memiliki perbedaan yang signifikan.

Berdasarkan kajian teori yang kami lakukan sebagaimana telah kami jelaskan sebelumnya bahwa konsep good governance memiliki tujuan akhir yang cendrung serupa yaitu efektifitas dan efesiensi.

Efektif dalam artian segala misi atau kegiatan yang dilaksanakan pemerintah harus terlaksana sesuai dengan perencanaan yang telah dilakukan. Namun efektivitas ini harus dibalut dengan efesiensi. Efesiensi dalam artian problem solution dan implementasi dari rencana yang dilaksanakan pemerintah harus cepat dan mudah baik dalam menerima data informasi maupun dalam mengambil tindakan. Tindakan yang diambil juga menggunakan sumberdaya yang minimal.

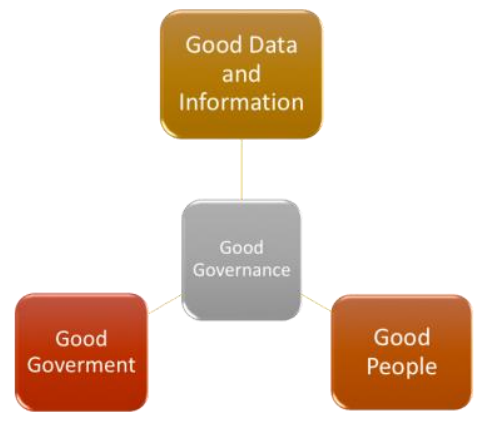

Gambar 1. Skema Good Governance

Berdasarkan Kajian Teori di atas, kita bisa membuat sebuah konsep good governance yang bisa di terapkan di Kabupaten Inhil. Pada dasarnya telah banyak konsep good governance yang berkembang, namun konsep yang dibuat disini disusun sesederhana mungkin mengingat resource Kabupaten Inhil miliki sangat terbatas.

Good governance setidaknya memiliki 3 komponen yang saling berkaitan untuk membentuk good governance. Tiga komponen itu adalah Good Data and Information, Good People, dan Good Government. Adapun penjelasannya adalah sebagai berikut.

a. Good Data and Information

Dari konsep di atas dapat disimpulkan bahwa kunci awalnya adalah data dan informasi. Data dan informasi yang masuk dengan sangat mudah, setelah data dimiliki data harus terintegrasi dengan sangat kokoh, lalu data bisa keluar dengan mudah baik ke masyarakat maupun antar opd dan aparatur pemerintahan.

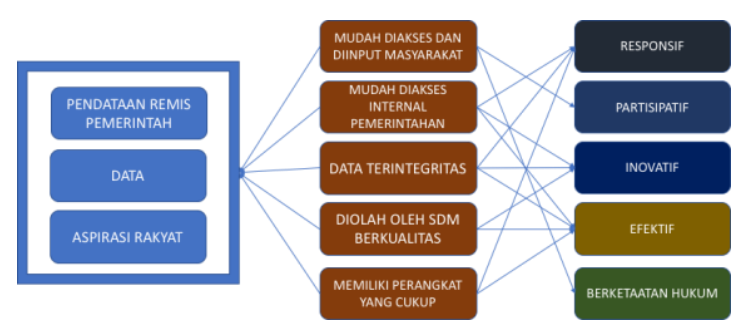

Gambar 2. Skema Data dan Informasi Sebagai Kunci Tata Kelola Pemerintahan 
Skema di atas menunjukan bahwa aliran data dan informasi harus mengalir dengan baik. Mudah diakses oleh masyarakat dan pemerintah adalah hal yang utama, ditambah dengan mudahnya masyarakat memberikan data dan informasi baru, terintegritas satu dan lainnya, serta yang terakhir diolah oleh SDM dan perangkat yang cukup

Konsep ini pada dasarnya tidak harus diharus dengan teknologi tinggi atau mumpuni. Pada tahap awal karakteristik di atas bisa diimplementasikan sifatnya saja.

b. Good People

Konsep ini merujuk pada masyarakat di luar pemerintahan. Seperti masyarakat awam, tikoh masyarakat, komunitas masyarakat, dll. Dikarenakan output akhir dari good governance adalah pelayanan yang baik kepada masyarakat maka maka masyarakat harus dilibatkan. Baik sebagai sumber maupun target.

Masyarakat yang baik bisa dimanfaatkan guna meraih good governance, namun tentu good people tidak bisa diraih tanpa usaha.

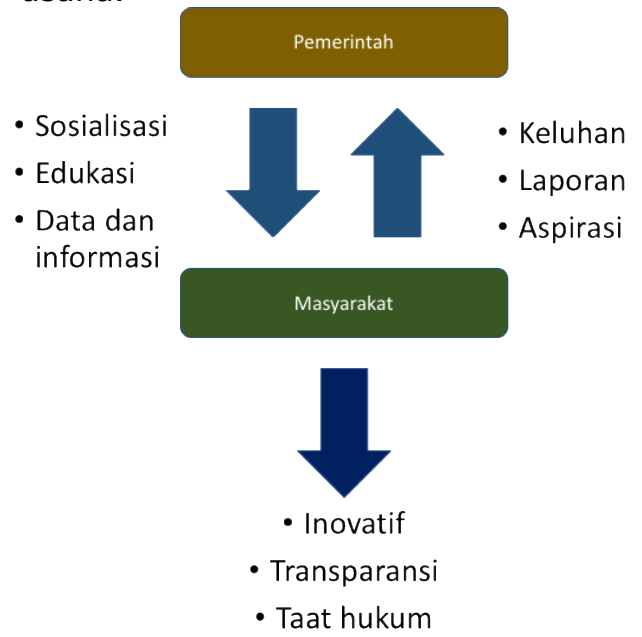

Sebagai sumberdaya masyarakat bisa dimanfaatkan untuk mendapatkan data dan informasi yang bersifat keluhan, aspirasi, serta laporan, guna meraih misi good governance yang responsif. Sedangkan, sebagai target masyarakat harus diberikan sosialisasi, edukasi, serta data informasi sebagai bentuk pelayanan pemerintah kepada masyarakat.

c. Good Goverment

Konsep terakhir yang menjadi motor penggerak utama adalah good government. Pemerintah yang baik harus memiliki sifat-sifat yang memenuhi kriteria good government berdasarkan kajian teori sebelumnya. Setiap opd di Kabupaten Inhil harus bersinergi dan menampilkan komunikasi yang baik guna mencapai 4 kriteria sifat.

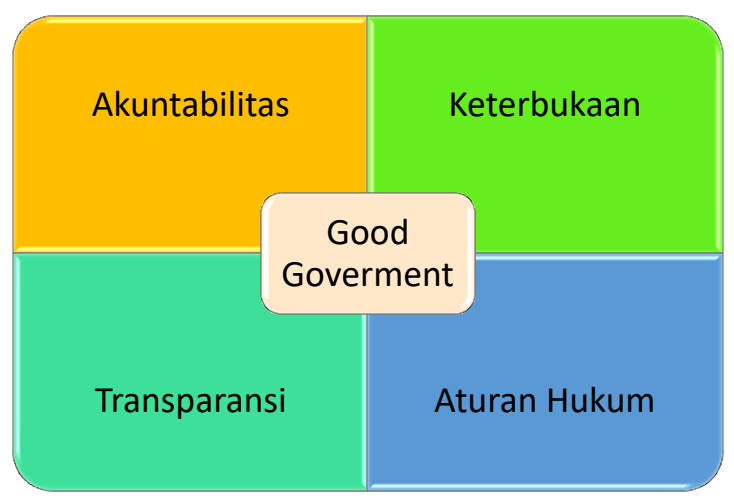

Gambar 3. Skema Good Goverment

Pemerintah harus akuntabilitas yaitu memenuhi kewajiban untuk memberikan pertanggungjawaban atau menjawab dan menerangkan kinerja dan tindakan seseorang/badan hukum atau pimpinan suatu organisasi kepada pihak yang memiliki hak atau berkewenangan untuk meminta keterangan atau pertanggungjawaban.

Pemerintah juga harus menjunjung keterbukaan terkait menerima aspirasi dari masyarakat serta memiliki transparansi terkait membagikan data dan informasi kepada masyarakat. Terakhir pemerintah harus menyiapkan aturan hukum yang kuat dalam usaha pemerintah menciptakan good governance agar usaha yang dilakukan kokoh diatas aturan yang berlaku. Konsep di atas ditegaskan pula oleh UNDP.

\section{KESIMPULAN}

a. Good Governance bisa diterapkan di Kabupaten Indragiri Hilir dengan sumberdaya yang ada

b. Good data and Information dalam konsep Governance tidak identik dengan teknologi tinggi.

c. Good People sangat dibutuhkan tapi membutuhkan beberapa usaha oleh pemerintah untuk menciptakan konsep Good People dia masyarakat

d. Masyarakat, Pemerintah, serta Data dan Informasi adalah tiga sumberdaya yang harus bersirkulasi dengan baik untuk 
mempermudah pelaksanaan Good Governance

\section{DAFTAR PUSTAKA}

[1] Ahmadi, Abu dan Suprijono, Widodo. 2000. Psikologi Belajar. Rineka, Jakarta

[2] Cipta. Halim, Abdul. 2014. Manajemen Keuangan Sektor Publik problematika penerimaan dan pengeluaran pemerintah. Selemba Empat, Jakarta

[3] Mardiasmo, 2002. Otonomi dan Manajemen Keuangan Daerah. Penerbit Andi, Yogyakarta

[4] Suaedi, Falih, Wardianto, Bintaro. 2010. Revitalisasi Administrasi Negara. Graha Ilmu, Yogyakarta

[5] United Nations Development Programme, 1999, 'Decentralization: A Sampling of Definitions', Joint UNDPGovernment of Germany Evaluation of the UNDP Role in Decentralization and Local Governance, Working Paper 